\title{
Short communication: Effect of pH on the heat stability of reconstituted reduced calcium milk protein concentrate dispersions
}

\author{
V. Sunkesula, ${ }^{1,2} \odot$ A. Kommineni, ${ }^{1}$ G. H. Meletharayil, ${ }^{1,3 *} \odot$ C. Marella, ${ }^{1,2} \odot$ and L. E. Metzger ${ }^{1}$ \\ ${ }^{1}$ Midwest Dairy Foods Research Center, Dairy and Food Science Department, South Dakota State University, Brookings 57007 \\ ${ }^{2}$ Idaho Milk Products, Jerome, ID 83338 \\ ${ }^{3}$ Dairy Management Inc., Rosemont, IL 60018
}

\section{ABSTRACT}

This study aimed to investigate the heat stability of dispersions from reconstituted reduced-calcium milk protein concentrate (RCMPC) with $80 \%$ protein or more. The tested RCMPC powders were produced from skim milk subjected to $\mathrm{CO}_{2}$ treatment before and during the process of ultrafiltration. The $\mathrm{CO}_{2}$ injection was controlled to obtain 0 (control, no $\mathrm{CO}_{2}$ injection), 20, 30 , and $40 \%$ reduction in calcium levels in the RCMPC powders. The RCMPC powders were reconstituted to $10 \%$ (wt/wt) protein in deionized water. These dispersions were tested for heat stability in a rocking oil bath at $140^{\circ} \mathrm{C}$ at unadjusted, $6.5,6.7,6.9$, and $7.1 \mathrm{pH}$. Calcium ion activity (CIA) and ionic strength measurements were carried out using a $\mathrm{Ca}$ ion-selective electrode and conductivity meter. Unadjusted $\mathrm{pH}$ of the dispersions varied from 6.8 in control to 5.96 in $40 \%$ RCMPC dispersions. The CIA of unadjusted dispersions ranged from $1.31 \mathrm{~m} M$ in control to $2.83 \mathrm{~m} M$ in $40 \%$ RCMPC. Heat stability, expressed as heat coagulation time (HCT) of unadjusted dispersions decreased as the level of Ca removal in powders increased (from $13.81 \mathrm{~min}$ in control to $0.46 \mathrm{~min}$ in $40 \% \mathrm{RCMPC}$ ) and was negatively correlated with the CIA of the dispersions. For control RCMPC dispersions, the minimum and maximum heat stability were observed at dispersion $\mathrm{pH}$ of 6.5 and 6.9 , respectively, followed by a decrease at $\mathrm{pH} 7.1$ (CIA was the lowest). Dispersions from $40 \% \mathrm{RCMPC}$ and $\mathrm{pH}$ 7.1 had the maximum HCT of 30.94 min among all RCMPC dispersions at all $\mathrm{pH}$ values. From this study, it can be concluded that improved heat stability in high protein formulation beverages subjected to UHT processing could be achieved through calcium reduction in milk protein concentrates using $\mathrm{CO}_{2}$ injection.

Key words: carbon dioxide injection, reduced-calcium milk protein concentrate, calcium ion activity, heat stability

Received May 21, 2020.

Accepted August 25, 2020.

*Corresponding author: hari.meletharayil@dairy.org

\section{Short Communication}

Milk protein concentrates (MPC) are second-generation dairy ingredients that contain caseins and whey proteins in the same ratio as in starting milk. They are typically produced by the partial removal of water, lactose, and minerals from skim milk using membrane filtration, nanofiltration, and spray drying. Milk protein concentrates with varying protein concentrations from 40 to $90 \%$ are available for commercial sale. Milk protein concentrates with a protein content of $\geq 90 \%$ are referred to as milk protein isolates. A pleasant dairy flavor, relatively lower carbohydrate content, and functional properties such as low viscosity, high solubility, water binding, foaming, heat, and emulsion stability make MPC a preferred high-protein ingredient in several food applications (Augustin et al., 2011). Typically, MPC with protein content up to $50 \%$ are used in cheese, yogurt, dairy desserts, salad dressing, and sauces. In comparison, MPC 80 and above $(>80 \%$ protein on DM basis) are used in ready-to-drink nutritional beverages and bars (Patel et al., 2014). Higherprotein MPC powders such as MPC80 undergo a loss of solubility during shelf life. A strong negative correlation between calcium content and MPC solubility was established by Marella et al. (2015). Unit operations such as high-pressure homogenization, extrusion-porosification, microfluidization, and ultrasonication of liquid concentrate before spray drying, mineral modification by the addition of monovalent ions during diafiltration, and cation exchange are different options to improve the functionality of MPC powders. Injection of $\mathrm{CO}_{2}$ before and during the UF process is an approach that has been studied to reduce the $\mathrm{Ca}$ content of the powders to improve MPC functionality (Marella et al., 2015).

Heat stability of milk is known to be influenced by ionic strength, milk salts, and milk proteins (Singh and Creamer, 1992). The reduction of Ca content to improve solubility during storage of MPC powders could also help with improving the heat stability of dispersions containing reduced-calcium MPC powders. Highprotein beverage applications involve the reconstitution 
of MPC80 powders, followed by thermal treatments such as UHT and retort processing, making heat stability an important criterion for the selection of MPC powders. Several studies have established the role of calcium in the heat stability of milk and the relationship between heat coagulation time (HCT) and $\mathrm{pH}$ (Singh, 2004). High calcium ion activity (CIA) has a negative effect on the heat stability of unconcentrated and concentrated milk systems (Philippe et al., 2003; Sievanen et al., 2008). Alteration of ionic balance during the manufacture of MPC powders and changes to Ca equilibrium during reconstitution of MPC powders result in dispersions with a different ionic calcium content $\left(\mathrm{Ca}^{2+}\right)$ compared with skim milk (Crowley et al., 2014). The $\mathrm{pH}$ of the dispersion also influences the ionic $\mathrm{Ca}^{2+}$ in the reconstituted MPC dispersion. Therefore, reducing $\mathrm{Ca}$ content during MPC manufacture through $\mathrm{CO}_{2}$ injection (to aid in superior reconstitution behavior during the powder shelf life) and adjusting the $\mathrm{pH}$ of the reconstituted dispersion may influence the heat stability of dispersions when reconstituted and subjected to high thermal treatments.

The aim of our study was to evaluate the effects of different levels of $\mathrm{Ca}$ reduction in MPC powders (RCMPC), by controlling $\mathrm{CO}_{2}$ injection during their manufacture, on the heat stability of the resultant reconstituted MPC dispersions. In the reported study, heat stability and CIA of RCMPC80 dispersions were studied at 4 levels of calcium reduction $(0,20,30$, or $40 \%$ ) of RCMPC 80 powders and 5 levels of dispersion $\mathrm{pH}$ (unadjusted or $\mathrm{pH} 6.5,6.7,6.9$, or 7.1 ). The RCMPC powders were produced 3 times from a fresh lot of skim milk. The RCMPC80 powders were prepared from skimmed pasteurized milk $\left(72^{\circ} \mathrm{C}\right.$ for $\left.15 \mathrm{~s}\right)$ at $\sim 10^{\circ} \mathrm{C}$ by injecting $\mathrm{CO}_{2}$ prior to and during UF using $10-\mathrm{kDa}$ spiral-wound polyethersulfone membranes (Marella et al., 2015). Skim milk was injected with 2,200 ppm $(\mathrm{mg} / \mathrm{L})$ of dissolved $\mathrm{CO}_{2}$ before UF, and the level was maintained during the UF process with additional injection. The retentate was spray dried and stored until further use. The composition of the RCMPC 80 powders is given in Table 1 . The RCMPC80 powders were reconstituted to $10 \%$ protein in demineralized water, stirred for $20 \mathrm{~min}$, and left overnight in a refrigerator. Sodium azide was used as a preservative $(0.02 \%$, wt/ wt). Samples were equilibrated to $30^{\circ} \mathrm{C}$ in a water bath following overnight storage. Apart from a sample set that was unadjusted for $\mathrm{pH}$, the $\mathrm{pH}$ of the dispersions was adjusted to either $6.5,6.7,6.9$, or 7.1 using $0.1 \mathrm{M}$ $\mathrm{NaOH}$ or $0.1 \mathrm{M} \mathrm{HCl}$ solution. Samples were allowed to equilibrate for $2 \mathrm{~h}$, followed by minor, if any, readjustments of $\mathrm{pH}$. The CIA and ionic strength of the all the RCMPC80 dispersions were measured using an Orion Versa Star calcium ion-selective electrode and an Orion Versa Star conductivity module attached to an Orion Versa Star meter (Thermo Fisher Scientific, Waltham, MA). The instrument was calibrated, and standard curves for ionic strength and CIA were developed using $\mathrm{KCl}$ at $10,20,40,60$, and $80 \mathrm{mM}$ concentrations and $\mathrm{CaCl}_{2}$ at $0,0.25,0.5,1.0,2.0$, and $3.0 \mathrm{mM}$ levels, respectively, and the same were used for calculations. Heat stability of RCMPC80 dispersions was determined by HCT, the time in minutes required for the dispersion to visually coagulate at $140^{\circ} \mathrm{C}$ (Singh, 2004). To measure HCT, $3 \mathrm{~mL}$ of dispersion in a securely capped glass tube was placed on a clamp frame connected with the rocking arm in an oil bath maintained at $140^{\circ} \mathrm{C}$, and the time taken to develop visual coagulation was recorded (Sutariya and Patel, 2017; Pandalaneni et al., 2018)

Reducing the Ca content of MPC powders by $40 \%$ markedly improved the heat stability of the dispersions at $\mathrm{pH}$ values of 6.9 and 7.1. The mean HCT and CIA values of RCMPC80 dispersions with different Ca reduction and at different $\mathrm{pH}$ levels are summarized in Table 2. The unadjusted $\mathrm{pH}$ of the RCMPC80 dispersions was observed to decrease with greater reduction of $\mathrm{Ca}(6.72$ at $0 \% \mathrm{Ca}$ reduction to 5.96 at $40 \% \mathrm{Ca}$ RCMPC80) and resulted in an increase in CIA of dispersions that ranged from 1.17 to $2.83 \mathrm{~m} M$. Injection of $\mathrm{CO}_{2}$ to milk decreases the $\mathrm{pH}$ (Ma et al., 2003), increasing soluble calcium that, during the process of ultrafiltration and diafiltration, is partitioned into the permeate.

Control MPC80 dispersions had maximum and minimum HCT at pH 6.9 (20.29 min) and 6.7 (13.02 min),

Table 1. Composition of reduced-calcium milk protein concentrate (RCMPC) powders; values are means of 3 replicate experiments

\begin{tabular}{lcccc}
\hline RCMPC & $\begin{array}{c}\text { Protein } \\
(\%, w t / w t)\end{array}$ & $\begin{array}{c}\text { Lactose } \\
(\%, w t / w t)\end{array}$ & $\begin{array}{c}\text { Ash } \\
(\%, w t / w t)\end{array}$ & $\begin{array}{c}\text { Calcium } \\
(\%, w t / w t)\end{array}$ \\
\hline Control & 77.02 & 6.41 & 6.88 & 2.16 \\
20\% Ca reduction & 77.57 & 6.46 & 5.81 & 1.84 \\
$30 \%$ Ca reduction & 77.82 & 6.88 & 4.95 & 1.48 \\
$40 \%$ Ca reduction & 78.08 & 7.93 & 4.67 & 1.34 \\
\hline
\end{tabular}


Table 2. Mean $(\mathrm{n}=3)$ heat coagulation time (HCT) and calcium ion activity (CIA) values of reconstituted reduced-calcium milk protein concentrate ( $>80 \%$ protein on DM basis) powder dispersions (10\% protein) at different $\mathrm{pH}$ levels ${ }^{1}$

\begin{tabular}{|c|c|c|c|c|c|c|c|c|c|c|}
\hline \multirow{2}{*}{$\begin{array}{l}\mathrm{Ca} \\
\text { reduction } \\
(\%)\end{array}$} & \multicolumn{5}{|c|}{ HCT (min) } & \multicolumn{5}{|c|}{ CIA $(\mathrm{m} M)$} \\
\hline & UA & $\mathrm{pH} 6.5$ & $\mathrm{pH} 6.7$ & $\mathrm{pH} 6.9$ & $\mathrm{pH} 7.1$ & UA & $\mathrm{pH} 6.5$ & $\mathrm{pH} 6.7$ & pH 6.9 & $\mathrm{pH} 7.1$ \\
\hline 0 & $13.8^{\mathrm{b}, \mathrm{A}}$ & $14.13^{\mathrm{b}, \mathrm{A}}$ & $13.02^{\mathrm{bc}, \mathrm{B}}$ & $20.29^{\mathrm{a}, \mathrm{A}}$ & $8.37^{\mathrm{c}, \mathrm{C}}$ & $1.17^{\mathrm{b}, \mathrm{B}}$ & $2.09^{\mathrm{a}, \mathrm{A}}$ & $1.24^{\mathrm{b}, \mathrm{A}}$ & $1.09^{\mathrm{b}, \mathrm{A}}$ & $0.8^{\mathrm{c}, \mathrm{A}}$ \\
\hline 20 & $6.53^{\mathrm{b}, \mathrm{B}}$ & $11.7^{\mathrm{ab}, \mathrm{A}}$ & $20.73^{\mathrm{a}, \mathrm{A}}$ & $20.35^{\mathrm{a}, \mathrm{A}}$ & $8.54^{\mathrm{b}, \mathrm{BC}}$ & $1.84^{\mathrm{a}, \mathrm{B}}$ & $1.47^{\mathrm{ab}, \mathrm{B}}$ & $1.15^{\mathrm{bc}, \mathrm{A}}$ & $1.08^{\mathrm{bc}, \mathrm{A}}$ & $0.74^{\mathrm{c}, \mathrm{A}}$ \\
\hline 30 & $4.83^{\mathrm{c}, \mathrm{B}}$ & $13.54 b^{\mathrm{c}, \mathrm{A}}$ & $25.27^{\mathrm{a}, \mathrm{A}}$ & $27.76^{\mathrm{a}, \mathrm{A}}$ & $24.25^{\mathrm{ab}, \mathrm{AB}}$ & $1.92^{\mathrm{a}, \mathrm{B}}$ & $1.42^{\mathrm{b}, \mathrm{B}}$ & $1.07^{\mathrm{bc}, \mathrm{B}}$ & $1.13^{\mathrm{bc}, \mathrm{A}}$ & $0.78^{\mathrm{c}, \mathrm{A}}$ \\
\hline 40 & $0.46^{\mathrm{d}, \mathrm{C}}$ & $10.41^{\mathrm{c}, \mathrm{A}}$ & $21.18^{\mathrm{b}, \mathrm{B}}$ & $17.86^{\mathrm{bc}, \mathrm{A}}$ & $30.94^{\mathrm{a}, \mathrm{A}}$ & $2.83^{\mathrm{a}, \mathrm{A}}$ & $1.38^{\mathrm{b}, \mathrm{B}}$ & $1.02^{\mathrm{bc}, \mathrm{B}}$ & $0.95^{\mathrm{bc}, \mathrm{A}}$ & $0.68^{\mathrm{c}, \mathrm{A}}$ \\
\hline
\end{tabular}

${ }^{\mathrm{a}-\mathrm{d}}$ Mean values within the same row corresponding to HCT and CIA not sharing a common superscript are significantly different $(P<0.05)$.

${ }^{\mathrm{A}-\mathrm{C}}$ Mean values within the same column corresponding to HCT and CIA not sharing a common superscript are significantly different $(P<0.05)$.

${ }^{1} \mathrm{UA}=$ unadjusted dispersion $\mathrm{pH}$ from $0,20,30$, and $40 \%$ reduced-calcium milk protein concentrate ( $>80 \%$ protein on DM basis) powders were $6.72,6.28,6.17$, and 5.96 , respectively.

respectively. A local minimum and a maximum in HCT are typical for Type A milk. The HCT decreased as the $\mathrm{pH}$ increased to 7.1. A decrease in CIA was observed in dispersions as the $\mathrm{pH}$ of the dispersions increased from 6.5 to 7.1 (from $2.09 \mathrm{mM}$ to $0.8 \mathrm{mM}$ ). For dispersions from 20\% RCMPC80, a similar trend to that of the control MPC dispersion was observed. Heat stability was least at $\mathrm{pH} 7.1$, and maximum HCT was seen in the $\mathrm{pH}$ range of 6.7 to 6.9 . The CIA also decreased as the $\mathrm{pH}$ of dispersions increased (from 1.84 $\mathrm{m} M$ to $0.74 \mathrm{~m} M$ ). A minimum observed in HCT of control and $20 \%$ reduced RCMPC dispersions at $\mathrm{pH}$ 7.1 could be due to extensive dissociation of $\kappa$-caseins from the micelles combined with sufficiently high Ca ion activities (Crowley et al., 2014). Dispersions from $30 \%$ RCMPC80 powders showed no significant difference in HCT from $\mathrm{pH} 6.7$ onward. The CIA of the dispersions decreased with increasing $\mathrm{pH}$. Dispersions from $40 \%$ RCMPC80 powders showed an HCT profile with a maximum at $\mathrm{pH} 6.7$ and a minimum at $\mathrm{pH}$ 6.9 , with a further increase in HCT with an increase in $\mathrm{pH}$. The CIA decreased with an increase in $\mathrm{pH}$, a trend observed across all RCMPC dispersions. In milk, it is hypothesized that HCT is influenced by 2 different reactions: colloidal reaction and chemical cross-linking (Walstra et al., 2005). This hypothesis can be extended to MPC dispersions from $40 \%$ RCMPC80 powder, where it can be assumed that colloidal reaction drives the rate-determining step for heat coagulation due to dissociation of casein micelles and depletion of $\kappa$-caseins up to a $\mathrm{pH}$ of 6.9 . At $\mathrm{pH}$ values $>6.9$, increased micellar charge and low $\mathrm{Ca}^{2+}$ activity could lead to an increase in HCT.

To summarize, in RCMPC powder dispersions, an interplay of colloid reactions (CIA, ionic composition, and dissociation of caseins) induced by a combination of $\mathrm{CO}_{2}$ treatment and UF processes and chemical crosslinking can lead to differences in casein aggregation behavior on heating. With an increase in Ca removal during the manufacture of MPC, casein micelle dissociation and changes to the serum component (decrease in soluble calcium, phosphates, and citrates) can influence the heat stability of RCMPC dispersions. The increase in the CIA of the unadjusted pH RCMPC80 dispersions with increasing $\mathrm{Ca}$ reduction (and corresponding $\mathrm{pH}$ shift toward the acidic side) can be explained by a lower $\mathrm{pH}$. The CIA of control MCP80 $(0 \% \mathrm{Ca}$ reduction) was highest at $\mathrm{pH} 6.5(2.09 \mathrm{~m} M)$ and continued to decrease with an increase in dispersion $\mathrm{pH},(0.80 \mathrm{~m} M$ at $\mathrm{pH}$ 7.1). A similar trend of decreasing CIA values with increasing $\mathrm{pH}$ was observed in the case of RCMPC 80 dispersions across levels of calcium reduction $(20,30$, and $40 \%$ reduction), with CIA being the lowest at $\mathrm{pH}$ 7.1 (0.74, 0.78, and $0.68 \mathrm{mM}$ for 20,30 , and $40 \% \mathrm{Ca}$ reduction, respectively).

Thermal stability during processing (UHT and retort) as well as storage stability of beverages containing MPC is an important functional attribute for consumers and processors. As the application of MPC powders in high-protein dairy beverages in on the rise, this study provides valuable insights into the thermal behavior of Ca-reduced MPC powders in high-protein dispersions. An increase in heat stability with the use of $30 \% \mathrm{Ca}-$ reduced MPC powder and $\mathrm{pH}$ adjustment to $\geq 7.1$ in formulations can help with an increased run time of thermal processing equipment (an important economic consideration) apart from potentially improved storage stability in high-protein beverages.

\section{ACKNOWLEDGMENTS}

The authors gratefully thank and acknowledge the Midwest Dairy Foods Research Center (MDFRC; Minneapolis, MN), the Agricultural Utilization Research Institute (AURI; Crookston, MN), and Agricultural Experiment Station (AES; South Dakota State Univer- 
sity, Brookings) for financial support. The authors have not stated any conflicts of interest.

\section{REFERENCES}

Augustin, M. A., C. M. Oliver, and Y. Hemar. 2011. Casein, caseinates, and milk protein concentrates. Pages 161-178 in Dairy Ingredients for Food Processing. R. C. Chandan and A. Kalaria, ed. Wiley-Blackwell, Oxford, UK.

Crowley, S. V., M. Megemont, I. Gazi, A. L. Kelly, T. Huppertz, and J. A. O'Mahony. 2014. Heat stability of reconstituted milk protein concentrate powders. Int. Dairy J. 37:104-110. https://doi.org/10 .1016/j.idairyj.2014.03.005.

Ma, Y., D. Barbano, and M. Santos. 2003. Effect of $\mathrm{CO}_{2}$ addition to raw milk on proteolysis and lipolysis at $4^{\circ} \mathrm{C}$. J. Dairy Sci. 86:16161631. https://doi.org/10.3168/jds.S0022-0302(03)73747-3.

Marella, C., P. Salunke, A. Biswas, A. Kommineni, and L. Metzger. 2015. Manufacture of modified milk protein concentrate utilizing injection of carbon dioxide. J. Dairy Sci. 98:3577-3589. https://doi .org/10.3168/jds.2014-8946.

Pandalaneni, K., J. Amamcharla, C. Marella, and L. Metzger. 2018. Influence of milk protein concentrates with modified calcium content on enteral dairy beverage formulations: Physicochemical properties. J. Dairy Sci. 101:9714-9724. https://doi.org/10.3168/ jds.2018-14781.

Patel, H., and S. Patel. 2014. Milk protein concentrates: Manufacturing and applications - Technical report. US Dairy Export Council, Arlington, VA.
Philippe, M., F. Gaucheron, Y. Le Graet, F. Michel, and A. Garem. 2003. Physicochemical characterization of calcium-supplemented skim milk. Lait 83:45-59. https://doi.org/10.1051/lait:2002049.

Sievanen, K., T. Huppertz, A. L. Kelly, and P. F. Fox. 2008. Influence of added calcium chloride on the heat stability of unconcentrated and concentrated bovine milk. Int. J. Dairy Technol. 61:151-155. https://doi.org/10.1111/j.1471-0307.2008.00391.x.

Singh, H. 2004. Heat stability of milk. Int. J. Dairy Technol. 57:111119. https://doi.org/10.1111/j.1471-0307.2004.00143.x.

Singh, H., and L. K. Creamer. 1992. Heat stability of milk. Pages 621-656 in Advanced Dairy Chemistry. 1. Protein. P. F. Fox, ed. Elsevier Applied Science Publishers, London, UK.

Sutariya, S., and H. Patel. 2017. Effect of hydrogen peroxide on improving the heat stability of whey protein isolate solutions. Food Chem. 223:114-120. https://doi.org/10.1016/j.foodchem.2016.12 .013 .

Walstra, P., J. T. Wouters, and T. J. Geurts. 2005. Dairy Science and Technology. CRC Press, Boca Raton, FL.

\section{ORCIDS}

V. Sunkesula $\odot$ https://orcid.org/0000-0003-4561-819X

G. H. Meletharayil $\odot$ https://orcid.org/0000-0001-9183-1966

C. Marella () https://orcid.org/0000-0002-3903-596X 